\title{
TRANSFORMING INDIGENEITY
}

\author{
Urbanization and Language Revitalization \\ in the Brazilian Amazon
}

Transforming Indigeneity is an examination of the role that language revitalization efforts play in cultural politics in the small city of São Gabriel da Cachoeira, located in the Brazilian Amazon. Sarah Shulist studies how discussions and practices aimed at providing support for the Indigenous languages of the region shed light both on global issues of language revitalization and on the meaning of Indigeneity in contemporary Brazil.

São Gabriel is characterized by a high proportion of Indigenous people and an extraordinary amount of linguistic diversity, with nineteen Indigenous languages still spoken there today. Shulist explores the effects of urbanization, multilingualism, and state intervention in this setting, and how they relate to understandings of Indigeneity and the use and transmission of Indigenous languages. Drawing on perspectives from Indigenous and non-Indigenous political leaders, educators, students, and state agents, Transforming Indigeneity provides insight on the revitalization of Amazonian Indigenous languages in a context of major social change.

(Anthropological Horizons)

SARAH SHULIST is an assistant professor of Anthropology at MacEwan University. 


\section{ANTHROPOLOGICAL HORIZONS}

Editor: Michael Lambek, University of Toronto

This series, begun in 1991, focuses on theoretically informed ethnographic works addressing issues of mind and body, knowledge and power, equality and inequality, the individual and the collective. Interdisciplinary in its perspective, the series makes a unique contribution in several other academic disciplines: women's studies, history, philosophy, psychology, political science, and sociology.

For a list of the books published in this series see page 243. 
SARAH SHULIST

\section{Transforming Indigeneity}

Urbanization and Language Revitalization in the Brazilian Amazon 
(C) University of Toronto Press 2018

Toronto Buffalo London

www.utppublishing.com

Printed in Canada

ISBN 978-1-4875-0287-4 (cloth) ISBN 978-1-4875-2219-3 (paper)

@ Printed on acid-free, $100 \%$ post-consumer recycled paper with vegetable-based inks.

Anthropological Horizons

\section{Library and Archives Canada Cataloguing in Publication}

Shulist, Sarah, 1979-, author

Transforming indigeneity : urbanization and language revitalization in the

Brazilian Amazon/Sarah Shulist.

(Anthropological horizons)

Includes bibliographical references and index.

ISBN 978-1-4875-0287-4 (cloth). - ISBN 978-1-4875-2219-3 (paper)

1. Language revival - Brazil - São Gabriel da Cachoeira. 2. Indigenous peoples - Brazil São Gabriel da Cachoeira - Languages. 3. Language and languages - Brazil - São Gabriel da Cachoeira. 4. Urbanization - Brazil - São Gabriel da Cachoeira. 5. Multilingualism Brazil - São Gabriel da Cachoeira. 6. Social change - Brazil - São Gabriel da Cachoeira. 7. São Gabriel da Cachoeira (Brazil) - Ethnic relations. 8. São Gabriel da Cachoeira (Brazil) - Social conditions. I. Title. II. Series: Anthropological horizons

P40.5.L3572B73 $2017 \quad 306.440981 ' 13 \quad$ C2017-906088-0

This book has been published with the help of a grant from the Federation for the Humanities and Social Sciences, through the Awards to Scholarly Publications Program, using funds provided by the Social Sciences and Humanities Research Council of Canada.

University of Toronto Press acknowledges the financial assistance to its publishing program of the Canada Council for the Arts and the Ontario Arts Council, an agency of the Government of Ontario.

Canada Council for the Arts
Conseil des Arts du Canada

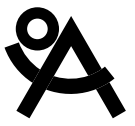

ONTARIO ARTS COUNCIL CONSEIL DES ARTS DE L'ONTARIO

an Ontario government agency un organisme du gouvernement de l'Ontario 